\title{
Téoros
}

Revue de recherche en tourisme

\section{Les hôtels « Romantik »}

\section{Jens Diekmann, Chantal Laliberté et Normand Cazelais}

Volume 5, numéro 3, novembre 1986

La gestion touristique : les nouvelles technologies

URI : https://id.erudit.org/iderudit/1080532ar

DOI : https://doi.org/10.7202/1080532ar

Aller au sommaire du numéro

Éditeur(s)

Université du Québec à Montréal

ISSN

0712-8657 (imprimé)

1923-2705 (numérique)

Découvrir la revue

Citer cet article

Diekmann, J., Laliberté, C. \& Cazelais, N. (1986). Les hôtels « Romantik ». Téoros, 5(3), 6-7. https://doi.org/10.7202/1080532ar d'utilisation que vous pouvez consulter en ligne.

https://apropos.erudit.org/fr/usagers/politique-dutilisation/ 


\section{Les hôtels "Romantik"}

by Jens Diekmann, with the assistance of Chantal Laliberté, étudiante en urbanisme, UQAM

\section{Marketing strategy of the Romantik Hotels and Restaurants Group}

\section{Market Analysis}

Since about the mid-sixties, the European hotel business has been going through a change in structure, which has been initiated by the establishment international hotel chains. owners. They saw that they had to develop new strategies to face increased competition. Co-operative reservation systems and other workshop groups were founded in order to fight against these highly capitalized chains, but the expected results never arrived.

\section{Jens Dickmann et le groupe Romantik par Normand Cazelais}

L'expérience de Jens Diekmann est exemplaire. L'histoire du groupe Romantik, qu'il raconte brièvement dans les lignes qui suivent, en témoigne. Elle démontre qu'en se donnant des objectifs clairs et des moyens de coopération efficaces et appropriés, de petits hôtels et des restaurants peuvent demeurer autonomes et personnalisés; elle démontre qu'ils peuvent, ensemble être capables de concurrencer avec succès les conglomerats et grandes chaines touristiques, tant à l'échelle régionale et nationale qu'internationale.

Selon Jens Diekmann, il importe pour ce faire de se fixer un certain nombre de principes de gestion et de bien les respecter par la suite. Pour le groupe Romantik, ces principes peuvent se résumer comme suit:

- garder le nom particulier de tous les établissements participants,

- établir une base de coopération qui implique l'égalité entre tous les partenaires,

- concevoir et diffuser des programmes de vente souples et adaptés au marché,

- mettre sur pied une solide organisation centrale et fournir aux adhérents des méthodes de gestion dynamiques.

Due to the absence of a marketing plan in the European hotel business these chain were in a favorable position to conquer markets that were out of reach for individual establishments. City administrations welcomed them open-armed, but it was quite the opposite attitude from the local hotel
En Europe -et cela le scra bientôt en Amérique du Nord-, les hôtels et restaurants Romantik sont devenus un label de qualité, une marque de commerce respectée et recherchée. Les gens qui les fréquentent sont en effet assurćs d'y trouver les propriétaires sur les lieux, un grand confort, une cuisine remarquable mettant en vedette des produits frais et les recettes du crû, un service fort soigné et un décor exceptionnel à des prix très concurrentiels.

11 m'a été donné de rencontrer Jens Diekmann à quelques reprises, dans le salon d'un hótel portant avec gráce quelques sic̀cles d'âge ou dans les jardins ombrés d'un restaurant fleurant bon le lilas, et de vérifier sur place le bien-fondé de sa démarche. Son court exposé le dit d'ailleurs clairement: dans le tourisme comme dans tous les autres secteurs d'activité économique, il n'y a pas de solution-miracle ni de formule magique; pour réussir, il faut une solide connaissance du marché, la volonté de mettre sur pied un produit à la fois authentique et original, et l'application soutenue de principes de gestion à la fois simples et très exigeants.

Most of these co-operative associations misjudged the signifiance of the name recognition of these hotel chains, thus underestimating their marketing power. The crucial point was not the capital of these chains, in most cases generated by national investors, but rather the well-known name which was the trade-mark of the group.

This had an attractive appeal on the customer (guest), the investor and last, but not least, on the city administration. Establishing a whole network of similar hotels in several countries enable these chains to shift the competition into an international level that was not within of the individual establishments.

A co-operative hotel association which wants to successfully complete against these hotel trust, therefore, has to consider the following points:

1. creation of an effective trade-mark in advertising,

2. focussing on a special market,

3. presence in different countries,

4. development of marketable sales programs.

The most important condition for a marketing co-operative the service trade-mark, was realised by only a minority. From the beginning, failure was in sight for most of the co-operatives leading naturally to the (wrong) conclusion that co-operatives are hardly possible or at least very difficult to organize, and that they can only be of limited success since too many different persons and opinions have to be co-ordinated.

Previous studies have shown that international chains with well-known service trade-marks are successful in Europe only if they adapt their marketing program to European consumption habits. This shows, however, that the European hotel business could well compete against these chains, since it has the following advantages:

1. profound knowledge of the regional market,

2. a good image in the home market,

3. and a well trained staff.

In the regional market, the good hotel or restaurant has a strong chance to compete 
